\title{
The (un)making of the Pax Turca in the Middle East: understanding the social-historical roots of foreign policy
}

\section{Clemens Hoffmann \& Can Cemgil}

To cite this article: Clemens Hoffmann \& Can Cemgil (2016) The (un)making of the Pax Turca in the Middle East: understanding the social-historical roots of foreign policy, Cambridge Review of International Affairs, 29:4, 1279-1302, DOI: 10.1080/09557571.2015.1119015

To link to this article: https://doi.org/10.1080/09557571.2015.1119015

Published online: 06 Jan 2016.

Submit your article to this journal $\sqsubset$

山 Article views: 892

View Crossmark data $\sqsubset$

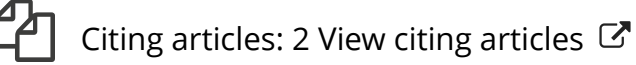




\title{
The (un)making of the Pax Turca in the Middle East: understanding the social-historical roots of foreign policy
}

\author{
Clemens Hoffmann \\ Bilkent University \\ Can Cemgil \\ Istanbul Bilgi University
}

\begin{abstract}
Turkey's foreign policy activism has received mixed reviews. Some feel threatened by the alleged increasing Islamization of the country's foreign policy, sometimes called 'neo-Ottomanism', which is seen as a significant revision of Turkey's traditional transatlanticism. Others see Turkey as a stable democratic role model in a troubled region. This debate on Turkish foreign policy (TFP) remains dominated by a sense of confusion about what appear to be stark contradictions that are difficult to make sense of. Intervening in this debate, this article will develop an alternative perspective to existing accounts of Turkey's new foreign policy. Offering a historical sociological approach to foreign policy analysis, it locates recent transformations in Turkey's broader strategies of social reproduction. It subsequently argues that, contrary to claims about Turkey's 'axis shift', its changing foreign policies have in fact never been pro-Western or pro-American. All foreign policy'shifts' and 'inconsistencies', weargue, areexplicable in terms of historically changing strategies of social reproduction of the Ottoman and Turkish states responding to changing domestic and international conditions.
\end{abstract}

\section{Introduction: the 'new' Turkish foreign policy-an axis shift?}

On 19 January 2014 a prosecutor in the Turkish province of Adana issued a search warrant for trucks delivering humanitarian goods destined for Syria. Instead of bandages, infusions and drugs, the Gendarmerie found weapons, allegedly destined for the al-Qaeda-affiliated Jabhat al Nusrah in Syria. ${ }^{1}$ While not the first or only allegation of such collusion between Turkey and Sunni extremists (Cheterian 2014), ${ }^{2}$ this nevertheless contrasts sharply with other Turkish actions (or inactions) in the Middle East. Allowing the transfer of Kurdish peshmerga fighters and their weapons from the Kurdish RegionalGovernment(KRG) controlled areas of northern Iraq into the embattled Kurdish enclave of Kobanî in northern Syria, held by the PYD (Partiya Yekîtiya Demokrat, or Democratic Union Party) and affiliated forces nominally inimical to the Turkish state, is seen as a 'dramatic shift in the

${ }^{1}$ Exchange of legal requests and notices between Adana's Public Prosecutor's Instructions Office and the General Staff Military Prosecutor's Office: <https:/ / anoninsiders.net/mit-documents-2867/>, accessed 24 January 2015.

2 Various media reports and allegations about the Turkish Armed Forces' (TSK) collusions with IS surfaced in the context of the September/October 2014 siege of Kobanî. 
Turkish position' by some observers. ${ }^{3}$ More recently, under pressure from the United States (US), Turkey finally joined the so-called anti-IS (Islamic State) coalition, allowing American jets to be based on Turkish soil, following a suicide attack in the southeastern town of Suruç targeting a socialist youth organization contributing to the reconstruction of neighbouring Kobanî. While Turkish commitment to the anti-IS coalition was applauded by US policymakers as a 'game changer' (Yeginsu and Cooper 2015), instead of hitting IS targets in Syria, Turkish jets started pounding PYD-affiliated PKK (Partiya Karkerên Kurdistanê, or Kurdistan Workers' Party) targets in Iraq and Turkey. Similarly, Turkey's energy cooperation with Russia clashes with its pro-Kiev position in Ukraine's civil war and the Russian support of arch-foe Syrian President Bashar Al-Assad. At the same time, Turkey has warmed up to the Shanghai Cooperation Organization, a body with clear anti-Western tendencies, and procured a Chinese missile defence system incompatible with the North Atlantic Treaty Organization's (NATO's) integrated structures while requesting protection from its partners against Syria using the US's Patriot missile system. Turkish foreign-policy-makers themselves claim to follow a 'multidimensional' approach (Davutoğlu 2008; 2012), whereas the ongoing academic and policy debates allege 'contradictions', 'failures', the 'end of the Turkish model' (Özpek and Demirağ 2014; Taşpınar 2014) and, most notoriously, an 'axis shift' compromising Turkey's traditional 'western anchors' (Çağaptay 2011). This article takes up this apparent disjuncture between the claims of Turkish policymakers and its observers and provides a new understanding of the current foreign policy conjuncture. It argues that tracing a deeper underlying inner 'logic' explaining all seeming contradictions and inconsistencies remains futile. To overcome the current impasse, this article offers a re-historicization of Turkey's regional and global relations up to the alleged 'axis shift'. This reveals that Turkey's contemporary foreign policy under Justice and Development Party (AKP) rule does not amount to a radical departure from the past. Paradoxical as the parallel pursuit of European Union (EU) accession, an active NATO membership and Turkey's declared ambition to create a 'new' or 'neo-Ottoman' order in the Middle East with the Muslim Brotherhood in the wake of the Arab Spring (Heydarian 2011; Edelman et al 2013, 7) $)^{4}$ may appear, they do not necessarily reflect a contradiction in the longer historical evolution of Turkey's foreign policy. Contrary to what is implied by an axis shift claim, we argue that Turkey's foreign policy has, in fact, never been pro-Western, or pro-American for that matter. All foreign policy 'shifts' and 'inconsistencies', we argue, are explicable in terms of historically changing strategies of social reproduction of the Ottoman and Turkish states in response to changing domestic and international environments.

Building on the historical materialist tradition of international relations (IR) and international historical sociology (Halliday 2002), we understand this contemporary conjuncture through a historically sensitive, materialist account of the longue durée

3 'Turkey to allow Kurdish peshmerga across its territory to fight in Kobani', The Guardian, 20 October 2014.

${ }^{4}$ Since 2011 the AKP has developed a discourse on 'New Turkey', indicating a shift in power away from the old 'Kemalist' elites towards a system with greater popular and peripheral representation-a model for socio-political renewal in the Middle East. Similarly, a 'New Middle East', borrowing both liberal and neoconservative foreign policy principles from the US and from nineteenth-century German imperial notions of geopolitics (Özkan 2014) is envisaged. For Turkey's new vision of the Middle East see also Şenyüz and Balıkçı (2015). 
of Turkish foreign-policy-making (Yalvaç 2014). ${ }^{5}$ Conceptually we deploy and develop Robert Brenner's notion of strategies for social reproduction (1985a; 1985b), which argued that in every social economy social classes are constrained by a set of 'rules for reproduction' based on their access to means of production. Large-scale social change, or 'economic development', in turn, is the aggregate and unintended result of the economically rational actions of individual actors who simply follow the rationality that these class-based 'rules for reproduction' impose on them (Brenner 1986). Unlike Brenner, however, we reject a structuralist notion of 'imposed rules for reproduction' that invariably apply to all individuals, constraining their actions (Brenner 1986; see Teschke and Lacher 2007). ${ }^{6}$ Nor do we limit reproductive strategies to actions of agents in relation to definite social property relations they find themselves in. Instead of defining strategies of reproduction in a material or political-economic sense only, we see them in the broadest sense, as all social action undertaken by social agents who, finding themselves in a given set of social relations, mostly unreflectively seek to maintain and at times better their position in relation to others. We further contend that states also devise strategies of social reproduction for themselves. These do not simply reflect dominant forms of social property relations (see Teschke 2003), nor are they exclusively geopolitical'strategies of spatialization' (Teschke and Lacher 2007). Reproductive strategies of states include, along with their foreign policy strategies, all state policies, and they must be understood as policy manifestations of temporary institutional results of the interplay of contradictory strategies of reproduction of a variety of social actors (Teschke and Cemgil 2014). While these involve political, economic, geopolitical and social policies, the concrete content of strategies of reproduction cannot be exhausted by exclusive geopolitical, political-economic or foreign policy analyses. The notion of strategies of reproduction requires an analysis that does not limit itself to the exclusive models of these disciplinary paradigms, but instead follows the footsteps of real agents (individual or collective) in history. Those agents do not and indeed cannot exclude, say, economic or cultural concerns when they make political decisions. ${ }^{7}$ Nor do states.

Accordingly, the Turkish state, as the locus of Turkey's foreign-policymaking, is not treated as an exclusive unitary agent, above and beyond the reach of other social forces, domestic and international. Similarly, we do not assume that the strategic determinants of foreign policy are related to one another through an external relation of causality within traditional foreign policy analysis (FPA) or IR frameworks. Rather, state policies and decisions are understood to represent the temporary equilibrium of the interplay of social agents that are situated in different spatial and temporal contexts with diverse motivations. Observable historical changes in the foreign policy of Turkey, in turn, are generated neither by a collective ideological dislocation, Islamist or otherwise, nor by the requirements of a given international system (whether bipolar or unipolar). Nor can the whims, personalities or leadership styles of bureaucratic (foreign policy) elites explain

5 Though Yalvaç's critical realist call for historicizing Turkey's foreign policy strategy is conceptually and theoretically convincing, he does not actually take on the task at hand.

${ }^{6}$ To break the rigidity of the concept of 'rules for reproduction', Teschke and Lacher $(2007,571)$ offer a more open notion of 'ways of reproduction' which denotes the availability of the myriad ways in which social agents may respond to so-called 'structural imperatives'.

7 This also indicates that agents of foreign policy are multiple and cannot be enumerated in a preconceived model or taxonomy. They may range from a trade union to a finance minister. 
changes in Turkey's foreign policy. They can, however, be understood as longterm consequences of the inter-subjective formation, consolidation, contestation and re-formation of a thus understood complex, spatio-temporally specific strategy of social reproduction. The specific foreign policy strategy of the AKP government discussed here involves establishing a Turkish sphere of influence in the former Ottoman geography by exploiting the power vacuum after the so-called Arab Spring. It employs means usually associated with soft-power projection but also more material forms of power. We conceptualize this spatio-temporally specific strategy here as the 'Pax Turca'.

To understand the constitution of Turkey's strategies of reproduction, we proceed with their historical-social-relational reconstruction. Our account starts chronologically with the genesis of the institutional configuration deploying this strategy in thelateOttoman Empire and the early Turkish Republic. It traces Turkey's contemporary foreign policy conjuncture from the late Ottoman transformation through the Cold War and identifies a fundamental change in state-society relations resulting from the AKP's rise to power. This stopped the sidelining of the religious masses practised by Republican state elites, something referred to here as Turkey's long-standing 'social question'. In effect this transformation 'democratized' society while the 1980s neoliberal transformation enabled the regional and global market expansion of the AKP's 'hegemonic' project (Tuğal 2009). The resulting 'majoritarianism' or 'populism' described by some observers of Turkish politics also has foreign policy implications (Öniş 2014). While nominally complying with a minimal notion of ballot box democracy, its credibility is increasingly undermined by authoritarianism at home (Ayata 2015). This is counteracted by the government's strong opposition to military authoritarianism in Egypt and its continued support of the Muslim Brotherhood, thus increasing its electoral appeal to religious conservative voters. Hence, this policy follows both a domestic electoral as well as a regional power strategy. Conversely, the collapse of the Arab Spring reversed most Western foreign policy preferences back to the 'old' military regimes. Turkey's continued support for social forces associated with 'Islamism' subsequently fuelled accusations about Turkey's 'axis shift' (Cornell 2012; Demirtaş-Bagdonas 2012).

Revisiting those social origins of these shifts demonstrates that the dichotomy between 'Western' and 'Eastern' orientation is analytically wrong and ideologically charged. Instead of an ideological predisposition as Sunni Islamist, Turkey's foreign policymaking is about generating space for more independent action. Since these actions do not take place in a vacuum, the real contradictions they generate, including irritations in the West, are by no means exceptional or specific to Turkey. Even if perceived inconsistencies multiply, these were never tantamount to an entirely pro-Western foreign policy, nor did they amount to a clear break with Turkey's Western anchors. Analysing contradictory social relations generative of contemporary Turkish foreign policy (TFP), including its changing geopolitical and political-economic environment, we intend to make sense of them sociologically as a longer-term result of contradictory strategies of social reproduction by a diversity of social agents. In doing so, the article contributes to a growing theoretical literature using historical sociological and social-relational approaches for analysing IR in general and TFP in particular (Bilgin 2007; Demirtaş-Bagdonas 2014; Bilgiç 2015) as well as the theoretical literature on Marxist historical sociology of IR (Lapointe and Dufour 2012). While many voices have called for this materialist 
historicization of foreign policy, these calls remained formulated in abstract terms. By contrast, this article offers to develop an original approach in the light of the concrete historicization and contemporary empirical analysis of a specific set of agents making the Turkish polity and its foreign policy.

\section{The Ottoman legacy and the formation of the Republic: the long revolution from above}

Rather than looking at the development of Republican or AKP foreign policy in isolation, our account takes the late Ottoman strategies of social reproduction as its starting point. This state reproduced itself primarily on three bases: direct extraction of surplus from independent agricultural producers through its functionaries, territorial expansion, and control of long-distance trade routes (Keyder 1987, 14). The loss of control of long-distance trade as a result of European discoveries of alternative trade routes was accompanied by the loss of access to agricultural taxes to the ayans (the local notables). The central authority was now dependent on the ayans both for purposes of taxation and for troops (Zürcher 2004). The inability to raise taxes to feed its huge military crippled the ability of the state to expand territorially, dealing another blow to its reproductive capability. By the nineteenth century, it became obvious that the Ottoman military was no match for the armies and navies of the modernizing Great Powers. Both to match the geopolitical challenge and to curb the power of the ayans, the Ottoman Palace undertook military and administrative reforms, in effect strengthening the social position of the military along with a new group of bureaucrats and state functionaries.

The Palace consequently thwarted the challenge from the ayans and established itself as the sole authority in the provinces, granting rights to collect taxes to its functionaries (Keyder 1987, 15-17). Though this helped consolidate central power, more direct forms of taxation also bred social discontent in the peripheries and the Balkan provinces in particular, contributing to a process of territorial disintegration and further military-fiscal weakening (Hoffmann 2008). Military officers and the bureaucracy, socially strengthened by the reform process, were able to force Sultan Abdülhamid to declare a (temporary) constitutional monarchy in 1876, consolidating their position gradually as a ruling elite. Geopolitically the Empire could have collapsed in the nineteenth century had it not been for the British balancing strategy against Russia and France, which the Palace successfully exploited (Hale 2000, 18-21). The Western-oriented military-bureaucratic elite finally acquired full control of the state in 1908 in the form of the Committee for Union and Progress, or Young Turk movement, turning the once-absolute rule of the sultan into a mostly ceremonial monarchy. In brief, the central role the military-bureaucratic elite would come to play in Turkish politics was an unwitting result of the interplay of a set of contradictory strategies of reproduction by a series of actors including the ayans, the Palace, the Great Powers, the peasantry and the tradesmen, all of whom acted with different purposes or reproductive strategies in mind.

It was this rising military bureaucracy that also successfully resisted Allied designs for partition. The vision of one of the Young Turk officers, Mustafa Kemal Atatürk, and the state elite was as much modernist, anti-colonial 
and anti-Western as it was developmentalist, ${ }^{8}$ not entirely unlike the Soviet experience. ${ }^{9}$ The Republic established in 1923 combined a militarist state apparatus with a defensive Turkish national identity. Previously, 'Turkish' had only implied being of Muslim and possibly rural origin(Mardin 1969,271); ${ }^{10}$ however, 'the Kemalist doctrine was more interested in fabricating the new Turkish nation out of the Hittite and Sumerian legacies than in deriving the cultural sources of the Turkish "self" from the Ottoman legacy" (Yavuz 1998, 25). This also implied a secularization that replaced Islam as the source of legitimacy of the Empire (Karpat 2000, 2). Without historical precedent, 'Turkism' lacked appeal even within the group of the most radical advocates of Turkish nationalism. ${ }^{11}$ With the 'actual' Turks ill defined and most economically powerful elites either expelled or killed en masse (Bloxham 2005), the early Turkish state lacked the social base for a productive civil society, or bourgeois element; ${ }^{12}$ only a small amount of merchant capital, petty entrepreneurship, finance and urban intelligentsia was left by 1923. 'Emptied' in this way, political economy, state and society were run by officers and the bureaucracy, developing the country top-down, and detaching urban centres from the rural population in the process. This deepened divisions between 'smooth, Parisoriented statesmen [and] country bumpkins' (Mardin 1969, 274), contradicting Turkish nationalist thinkers such as Ziya Gökalp's visions (Parla 1985, 50f) of generating a more inclusive native Muslim civil society. In short, the new secular Turkish national developmentalism was deployed without penetrating society more deeply. State-society relations remained loose at best.

Given the absence of competing social forces (Yalman 2009, 159), the early Turkish Republic was characterized by a military-bureaucratic elite as the only policymaking and surplus-receiving class. The result was a 'politically strengthened' party-state, 'combating rival principles of social cohesion, while allowing development of the market' (Keyder 1987, 90) through agents recruited from the state elites. The success was twofold in that the entrepreneurial elites not only contributed significantly to the envisioned form of 'ethnic' Turkish capital accumulation as a strategy of national reproduction, thereby providing a strong fiscal base for the new nation state and its military build-up, but also ideologically, by building a new private-public 'bureaucratic bourgeoisie' as a social base for Turkey's new order. State elites were, in other words, not identical with the accumulation process itself, but ideologically and personally wedded to it, providing incentives such as tax breaks, but also distributing the spoils of war amongst selected entrepreneurial families. The early Turkish state was, thus, characterized neither by the institutional separation of a 'private' economy and a 'public' state (see Wood 1981), nor by a purely state-led Soviet-style development programme.

\footnotetext{
${ }^{8}$ Though it was also anti-communist, it only became anti-Soviet in the light of Stalin's designs on the Turkish Straits.

${ }^{9}$ These and other similarities in their anti-Western state-forming history laid the foundations for a friendship between the early Turkish Republic and the Bolshevik regime, which was later undermined by Stalin's designs on Kars and the Straits.

${ }^{10}$ The urban intelligentsia was mostly non-Muslim, of Greek, Jewish and Armenian origin; see for example Braude and Lewis (1980, Part 4).

${ }^{11}$ For a historical account of attempts to define Turkishness during the early years of the Republic, see Çă̆aptay (2006).

12 According to Zürcher (2004), prior to the formation of the Republic over 90 per cent of the industrial establishments with more than ten workers were owned by non-Muslims.
} 
Instead, it was characterized by a personal union of the military, the bureaucracy and a newly engendered entrepreneurial class, an alliance maintained by the rise of Turkish nationalism and Kemalism, the secular state ideology built on modernizing Turkey along Western lines as formulated by Atatürk (Atabaki and Zürcher 2004; Anderson 2008). Quite unlike in other late-coming nations like Japan, Germany, Italy or Russia, capitalism emerged from neither a reforming absolutist dynasty or an alliances of nobles or revolutionary or anti-colonial movements, but straight from a professional officer corps and conjoined bureaucratic class emerging from a long-term, geopolitically mediated modernization project.

Geopolitically, the success of this anti-Western defensive state formation in 1923 coincided with the consolidation of the Bolshevik Revolution. This opened, amongst other things, a window of opportunity for friendly relations with Moscow and Berlin at the same time. Thus freed from all geopolitical straitjackets Atatürk advocated 'peace at home, peace in the world', though notably without joining the anti-fascist camp. Decreased fiscal-military pressures allowed protectionist and statist development policies by 1929. The inter-war contraction of agricultural markets led to a capital and labour scarcity, aiding urban growth as well as mechanization. Productivity increases kept food prices low, indirectly aiding further urban-industrial expansion (Pamuk 2000, 335) while agriculture could capitalize by replacing the war-torn depleted Soviet and German production. Geopolitically, Turkey started developing strategies and making clear choices. Its so-called 'active neutrality' (Deringil 1989, 133f) in favour of Nazi Germany, without giving up its friendly relations with Moscow, showed the first signs of integrating TFP into Kemalist strategies of reproduction. It developed a realist geopolitical selfunderstanding as a central-defensive state (Bilgin 2007) whose interests were best served by a specific strategy-in this case a neutral but informally pro-German one. At the same time the military bureaucracy consolidated the dominance of the Western, urban military bureaucratic state class over the rest of the country. This set the parameters for Turkey's further development. Political institutions remained far removed from large parts of society while foreign policy was maintained independently to serve Turkish interests (Yavuz 2003, 46-48).

In sum, the early twentieth-century Turkish Republican development is exceptional if compared with either the European or the Middle Eastern context. Its military-fiscal consolidation cultivated a set of distinctive capital relations and related foreign policies during its founding years. The introduced European institutions lacked 'any synthesis with local tradition' (Yavuz 2003, 87) or "'organic links", i.e., no basis of power in the society' (Yalman 2009, 265). Their raison d'état thinking institutionalized the belief that the state had to react to external imperatives first, implying a 'primacy of the state over society' (Yavuz 2003, 265). This generic tendency also came to characterize capital-labour relations. Here discipline and repression was the policy of choice from the start (Yalman 2009, 187) and had severe consequences, as the following section will demonstrate. Relatedly, that is, in response to an unresolved and therefore potentially explosive 'social question', the state started regulating Islamic preaching through the Religious Affairs Directorate (DİB). ${ }^{13}$ This owed not so much to a fear

${ }^{13}$ Official Turkish title: Diyanet İşleri Başkanlı̆̆ı (Presidency of Religious Affairs); the office also runs a sister organization in Germany which is concerned with the religious affairs of the large Turkish immigrant community there, the Turkish-Islamic Union for Religious Affairs: Diyanet Işleri TürkIslam Birliği (DİTiB) 
of political Islam itself as, given the level of repression, to a fear of the social forces that it might come to represent. As a result, recurrent military interventions in the formal democratic process were justified as a means to prevent the 'Islamization' of politics in reaction to electoral gains by Islamic parties and alleged external 'Islamic' threats.

Another perceived threat to the social cohesion of the new state was the presence of the Kurds. While the Kurds had not developed a coherent national project during the first years of the Turkish Republic, following the exclusionary practices of the new Kemalist state, they staged a series of uprisings against the state, planting the seeds of a future national imagination. The state increasingly resorted to repressive measures, ranging from the prohibition of the Kurdish language to excluding Kurds from political processes (McDowall 2004, 184f). Repression and exclusion, accompanied by a series of massacres of Kurds, became the primary policy of the Turkish state until the 1980s, when the Kurdish political movement reinvigorated itself through a formerly Marxist, then ethno-nationalist and now democratic confederalist ${ }^{14}$ (Yarkin 2015, 28) armed insurrection against the state (Güneş 2012). Along with the religious movements, the Kurds constituted a rival political project against the secularist military-bureaucratic regime.

After the contingencies of disruptive post-war developments had produced social instability followed by a military coup in 1960, the state deployed development policies and strategies more directly. A new constitution was adopted along with Soviet-style five-year plans aimed at further developing urban, state-owned industrial production, leading to the consolidation of powerful trade unions. The emerging Import Substituting Industrialization (ISI) regime remained in essence the core strategy of social reproduction until the crisis of the 1970s. It generated urban industrial growth, a growing labour movement and a strengthening agricultural sector without, however, fundamentally altering Turkey's social relations. Externally, it institutionalized the dependence on foreign imports and capital, leading to an endemic current account deficit that still characterizes external trade. ${ }^{15}$

The gradual, though never full, integration into world markets was now accompanied by a decided geopolitical shift westward, eliminating all pro-Soviet and non-aligned alternatives. Stalin's aggressive demands for free passage for the Black Sea Fleet (Coş and Bilgin 2010) and his designs on Kars proved to be catalysts for NATO membership in 1952, which was in tune with anti-labour and anti-communist positions at home. Hence, it constituted a strategic choice, not the expression of an ideological predisposition. While US Cold War strategy had always sought to integrate Turkey (Leffler 1985), having experienced occupation by Allied forces, the Turks' affinity towards the West developed only reluctantly

14 'Democratic confederalism' is a concept developed by the US anarchist thinker Murray Bookchin. He proposes the decentralization of power and the dissolution of hierarchies associated with the modern nation-state, patriarchal social structures and extractive industries through direct democracy, confederated municipal assemblies as the central decision-making bodies, and ecological self-sustainability (Bookchin 1982).

${ }^{15}$ Partly due to this dependency on foreign capital to pursue industrialization policies, Turkish historiography was influenced by the dependency school, which located the new state in the 'semiperiphery' of the capitalist world economy. Even though we do not concur with these arguments, the emphasis on international factors explaining socio-economic transformation in Turkey makes for a useful starting point; see, for example, Islamoglu and Keyder (1977) and Islamoglu (2004). 
until the Korean War sealed its Western commitment (Lippe 2000). The nature of the post-war political economy made integration into the Bretton Woods order indispensable, which itself left limited space for inward-looking industrialization policies (Yalman 2009, 113). This left Turkey in a dilemma between external financial dependence and the requirements of state-led industrialization, including the development of a domestic military-industrial complex (Yalman 2009, 177). The US remained reluctant to fund Turkish development and the military build-up as long as the market remained protected. This changed with Turkey's increasing strategic importance during the Cold War and eventually led to the Congressional approval of funds, making Turkey one of the largest recipients of US Cold War military aid (Yalman 2009, 182f). It was this valuable geostrategic position that eventually convinced Congress to fund not only arms but also development through what we call here a mechanism of geopolitical rentierism. ${ }^{16}$ Importantly, this alliance still clearly remained strategic, that is, determined by mutual, coinciding interests to maintain Turkish-American relations. And, as the following will show, those were about to diverge by the mid-1970s. Once established, this reliable source of finance not only helped industrialization, but also consolidated the Kemalist elites' grip on power. Conflicts were limited to negotiating the extent of the bureaucracy's rent-seeking activities, the maintenance of which required continuously high degrees of coercion. These included the large-scale use of force in recurrent coup d'états and the deployment of a so-called 'deep state' (Kavakçı 2009; Söyler 2013) made up of security and juridical elites, preserving the 'secular' order against all challenges, and using all available means, legal and illegal. This, too, would have implications for the way in which Turkey evolved as an international actor.

This high level of domestic coercion was not enough to curb social tensions. External dependency was soon to haunt Turkey's elites as a third geopolitical crisis made the instability of this regime of reproduction abundantly clear. The origins of this crisis lay far away from Turkey and the US, notably in the social contradictions of the Greek state and its military junta. The 1974 invasion of Cyprus was triggered by a coup d'état against its first post-colonial president, Makarios, devised by an all-but-bankrupt junta in Athens aiming to incorporate Cyprus into Greece (a political union referred to in Greek as 'Enosis'). Prime Minister Ecevit bowed to public pressure and intervened to protect the Turkish Cypriot community from allegedly imminent acts of ethnic cleansing. Though the initial invasion was covered by the 1960 Treaty of Guarantee establishing Cypriot independence, the subsequent and continuing occupation of one-third of the island caused major outrage around the world. It also led to a US Congress resolution against Turkey. As a result, Turkey was subjected to sanctions and the US Senate refused to pass a package allowing military assistance to Turkey as late as 1979 in spite of the expectation that Iran's Islamic Revolution had improved Ankara's secular favours in Washington. This geopolitical crisis coincided with and exacerbated an ongoing economic crisis. Prior to the invasion of Cyprus, the International Monetary Fund (IMF) had started demanding a more rigid exchange rate policy and Organization for Economic Cooperation and Development (OECD) led restructuring of debt. A capital shortage, as a result of the oil shocks and the global economic downturn,

${ }^{16}$ Another example being Egypt's dependence on US military aid, owing to the Camp David accords, that is, a source of funding generated through a shift in geopolitical relations. 
triggered high inflation, and foreign borrowing was finally exhausted by 1978 . With its chances of acquiring external funding minimized, Turkey went through a painful domestic adjustment-again implemented by excessive force (Yeldan 1995, 39). International financial institutions (IFIs), but increasingly Turkish capital too, started favouring a more radical adjustment towards export orientation to address Turkey's balance-of-payment crisis.

Under the crisis conditions of the late 1970s, despite continuous crackdowns, social contradictions spiralled out of control. The revolutionary anti-imperialist left and the rise of labour movements challenged the traditional reproductive conditions of the state while Islamic parties continuously grew their electoral base. Eventually the military intervened in 1980 to 'restore the secular order', or rather, in an attempt to deal with social tensions, targeted labour and left-wing activists first and foremost. Despite the banning of Islamic politicians and the imposition of the 'secular' constitution of $1982,{ }^{17}$ it had become clear that the statist-Kemalist model required adjustment-or hegemony in the true sense of relying on consent as well as coercion. To avoid the rise of labour and the left, Kemalist elites went on to pursue 'not only an Islamization of Turkish nationalism, but also ... the Turkification of the Islamic tradition' using moderate Islam as a means of consolidating Turkish social cohesion (Yavuz 1998, 30). This also laid the foundations for what would become known as the 'Turkish model' (see Taşpınar 2014).

As the foregoing narrative demonstrates, the Turkish Republic was not Western from the outset. Its central strategy of reproduction was based on establishing an autonomous polity, albeit along Western lines. While the post-1945 alignment with the capitalist bloc seems to challenge this narrative, when that is put into its concrete social-historical context it can be argued that Turkey's foreign policy at the time was a reproductive response of the Turkish state elites to multiple and contradictory pressures from a variety of domestic and external social actors. Crucially, these included the Soviet Union and a growing labour movement at home. Had the pre-war conjuncture remained unchanged, there is no reason why Turkey should not have remained a more autonomous actor in international relations as evidenced by Turkey's friendly pre-war relations with the Soviet Union and the wartime policy of 'active neutrality' towards Nazi Germany. Furthermore, the fallout with the US and the West in general following the Cyprus crisis until the 1980 coup is another instance whereby Turkey followed a strictly independent foreign policy reacting to domestic social pressure while hoping to restore its international standing via its indispensable geostrategic position. Yet again, geopolitical rentierism paid off, and the American embargo was lifted in 1978 despite Congressional opposition.

\section{The neoliberal turn and the expansion of 'Islamic capital'}

Under the military-ruled domestic adjustment, the former World Bank executive Turgut Özal of the Anavatan Party (ANAP) launched economic reforms aimed at export-oriented growth. In many ways, despite the preceding crises, the 1980

\footnotetext{
17 This constitution is currently still in force, though the government has recently launched a process to replace it with the overall aim of centralizing rule further and implementing a presidential system. This attempt came to a standstill when the Parliamentary Commission stopped working on it due to substantive disagreements between the parties represented in parliament.
} 
turn was not so much of a rupture with the past, but can rather be seen as the logical continuation of Turkey's catch-up with the global market. This peaked with full capital account liberalization in 1989. ${ }^{18}$ Özal, himself more of an Islamic conservative, exclusively reformed the realm of economic activity and left social relations untouched, maintaining authoritarian rule (Öniş 2004, 114). The decade following the 1980 military coup was therefore characterized by an attack on labour power in order to 'restructure the state' and eliminate class struggle from the political scene (Yalman 2009, 298-299). One aspect of this policy to counterbalance left-wing tendencies was to strengthen the role of religion in social relations. This eventually gave rise to the re-entry of Islamic parties into the political arena in the 1990s. More significantly, liberal reforms along Reaganite and Thatcherite lines stimulated unprecedented economic activity outside the urban centres. Independent entrepreneurship started developing in the peripheral provinces, such as Konya, Denizli and Kayseri, which showed marked differences from the state-led (yet privately owned) industrial conglomerates of Istanbul. While the Anatolian small and medium-sized capitalists and their religious networks would constitute the social and electoral base of the governing ANAP, the government's export promotion, market liberalization and anti-labour policies helped them to utilize an underpaid and in most cases unregistered workforce, previously producing for multinational companies. Moreover, these small and medium-sized entrepreneurs (SMEs), who came to enjoy exclusive state patronage, constituted a formidable rival to established Kemalist urban capital. Özal's preferential treatment of the frequently family-run SMEs, his favouritism towards family members and Islamic networks, the general socio-political instability of the 1980s and 1990s and chronic inflation all irritated the big capitalists, mainly represented by the Turkish Industrialists' and Businessmen's Association (TÜSİAD). This led to the exclusion of these newly emerging Anatolian capitalists from the latter's established networks. ${ }^{19}$ In response, smaller Anatolian capitalists established the Independent Industrialists and Businessmen Association (Müstakil Sanayici ve İşadamları Derneği-MÜSİAD) to represent their interests more specifically. ${ }^{20}$ The members of MÜSİAD not only enjoyed support from the government in many forms, but also benefited from religion and religious networks in disciplining labour as well as in generating, supplying and disbursing financing for their investments, and in servicing their debts. Ultimately, this triggered a process of political emancipation from the traditional elites, including the much-reported 'standoff' between the military and the government, eventually leading to the 'civilianization' of politics under the AKP's rule.

\footnotetext{
${ }^{18}$ It should be noted here that this adds not only yet another variety of capitalism, but also another variety of Islam. This is not necessarily to argue that amalgamating Islam and capitalism is a particularly novel or innovative project, but only that capitalism and Islam both have to be de-essentialized and understood as historically, socially and geographically specific concepts; see al-Ahmeh (1993) and Rodinson (1966)

${ }^{19}$ The sense of exclusion of the founders of MÜSİAD turned out to be the motivation for establishing the organization and reached its apogee when some later members of MÜSİAD were blocked from participating in an international business meeting organised by the Association of Foreign Economic Relations (Buğra 1998, 529).

${ }^{20}$ Conveniently, the Turkish word for 'Independent', that is 'Müstakil', had been considered to refer to the Islamic credentials of the association as well, the acronym ' $\mathrm{M}$ ' expressing both its Muslim and independent characteristics.
} 
This emergent Anatolian capitalist class thus generated a new kind of Islamic civil society in Turkey. More than just the opportunistic seizure of an ad hoc economic opening by previously non-propertied classes (Demir et al 2004, 169), the conditions for the rise of the small property-owning so-called 'Anatolian Tigers' (Hoşgör 2011), or 'Islamic Calvinists' (Yavuz 2003, 89), ${ }^{21}$ can be traced back to the foundations of modernization in the Ottoman Empire and the early Republican era, filling the space for a bourgeois development 'from below' (or 'out of the steppe'). Capital account liberalization allowed for the emergence of strong 'counterelites' outside the old statist consensus, leading to the formation of an independent capital base as well as an independent intelligentsia.

The emergence of this class was complemented politically by the rise of the Islamist Refah Party (RP) in the 1994 elections. This marked the ascent of a group of local politicians who would later constitute the backbone of the AKP, including the current president Recep Tayyip Erdoğan. Under Erdoğan's term as metropolitan mayor in Istanbul, water shortages, air pollution, fiscal problems of the municipality and many other problems of urban life were either solved or significantly ameliorated. Impressed with the unprecedented levels of public service provision (something the old Kemalist regime simply never thought of as politically imperative in the same way) wrapped in references to a just, prosperous and traditional Islamic order, and discontented with the three centre-right and centre-left parties, voters gave the RP a plurality in the 1995 general elections. Having emerged in the early 1970s in reaction to its exclusion from political and economic life, the Islamist movement could now capitalize on the decades-old failure of the social democrats and the centre-right to deliver on their promises of prosperity. In the 1980s, the RP's electoral base grew through a social conservatism popular with the rural masses, previously excluded Islamic capital and the religious networks of solidarity.

The military-bureaucratic elite was generally happy with the mix of neoliberal transformation and authoritarian rule. Internal and external security and foreign policy remained its exclusive domains. On top of its support for illegal paramilitary and criminal networks, the 1982 constitution it authored institutionalized this monopoly, introducing innumerable 'checks and balances', and indeed reprimanded successive elected governments when they sought to challenge it. Özal proved to be more accommodating of the military's demands when navigating the troubled waters of foreign policy and security; the RP, on the other hand, had a more comprehensive vision of society that also involved a new and Islamic foreign policy orientation ill regarded by the military. In a show of force, it compelled the RP to deepen relations with Israel and finally overthrew the government in 1997 in very sophisticated but bloodless ways, coining the phrase 'postmodern coup' (Öniş 2006).

As in previous decades, Turkey's foreign policy was not automatically pro-Western during the 1980s and 1990s either. The First Gulf War is a case in point. Although Özal wanted to support the American action against Iraq, the military were more prudent, fearing a spillover from the war. In the end, this conflict

${ }^{21}$ This concept denotes the idea of a property-owning, austere and hard-working class of religious entrepreneurs along the lines of Max Weber's thoughts on the origins of capitalism in Protestant religious doctrine and identity (see Weber 1920 ). 
resulted in a compromise with Turkey offering only logistical support. The establishment of friendly relations with Israel in the 1990s, in turn, was less the result of a pro-American policy than an attempt to break the international isolation of Turkey when Europe saw Turkey as 'the last Stalinist regime in Europe' (Robins $2003,13)$ due to its anti-democratic policies at a time when the world was celebrating the rise of human rights. These policies became particularly evident during Turkey's internal war against the PKK in the southeast of the country.

This demonstrates that Turkey's foreign policy has never been automatically pro-Western. In turn, one cannot simply claim that it has not undergone any changes under the AKP. Even before the AKP came to power, Turkey's foreign policy orientation and responses to individual international developments varied depending on the changing environment and the associated strategies of reproduction. The AKP, however, claimed to represent different sections of the capitalist and working classes, who believed, until the end of the century, that they were underrepresented, or even excluded from the relatively insulated Turkish state complex. The AKP, therefore, had a different vision and a different set of reproductive priorities than prior ruling elites. Whether, in fact, their practices constituted a fully different external strategy of reproduction is discussed in the following section.

\section{The rise of the AKP}

Out of this 'passive revolution' (Tuğal 2009), the AKP rose as the embodiment of a neoliberal reform agenda with popular appeal through the medium of political Islam. Although the current government relies heavily on authoritarian measures (Taşpinar 2014), it has nevertheless addressed Turkey's 'social question' much more successfully than the old elites. Its electoral success is wedded to the provision of public services, a consolidated fiscal base that depends on the expansion of a conservative consumer culture and associated credit markets (Öniş 2009) and, more recently, a programme of urban transformation and infrastructure provision expanding the economy through the construction-credit-retail nexus (Marois 2012). Political Islam, in turn, is no longer seen as representing 'the grievances of the poor and the disadvantaged in both rural and urban areas in a social democratic guise' (Öniş 1997, 478) like under the welfare-oriented RP preceding the $\mathrm{AKP}$, but as commensurate with capitalist growth and a new 'Calvinist' entrepreneurial spirit promoting full-scale integration into the G20 finance-led capitalist world economy. While labour (at least in the form of leftist parties and trade unions) continues to be a target, the AKP has successfully replaced public welfare with religious benevolence and charity.

The AKP's strategies of reproduction are conscious of the RP's demise in 1997. Aware of the military's, the judiciary's and the bureaucracy's sway over power structures, the AKP sought to appease the generals by limiting its activities to economic recovery and harmonization with the EU acquis communautaire from the outset. Their ability to continue ruling, let alone wielding power freely in government, was contingent upon the tolerance, if not the blessing, of the old establishment. In response the AKP followed a carefully crafted strategy of accommodating not only the generals, but also the established capitalists of the Republican ancien régime, the mainstream media, as well as the US and the EU. All of these strategies were carefully deployed, conscious of the historical pattern that, time and again, Islamist parties were driven out of power. 
The key pillar of this strategy of reproduction was, fundamentally, the promise to elevate more people into wealth and prosperity. This generated electoral support, contingent on economic growth, gradually earning Turkey the status of one of the world's 'emerging markets' and 'rising powers' (Cam 2002). In pursuit of this reproductive path more reforms were carried out to improve the rule of law, human rights, civil-military relations, the accountability of the judiciary and the security forces, and minority rights. This naturally enlisted the support of the Western world and particularly the EU. Erdoğan and the AKP assured successive US administrations about their market-friendly credentials and tried to act as a conduit to open up Middle Eastern markets to neoliberal accumulation while continuing to liberalize the domestic market. Soon enough, this earned Turkey a 'model' status for the entire region (Atasoy 2011). The EU anchor and US support provided much-needed external legitimacy to AKP rule when EU membership negotiations started in late 2005. This further enabled the government to curb the powers of the General Staff, overcoming much resistance from the old regime. It was not only the EU accession process and the blessing of the US government, but also the widespread support from the general populace, not merely the AKP constituency, from liberal democrats to the liberal left and segments of the socialist left, that empowered the AKP government to push the military out of politics by democratizing civil-military relations (Michaud-Emin 2007). The military mostly stayed out of politics because the top brass along with the rest of the officers had a stake in the stable growth of the economy through their own entrepreneurial activities (Demir 2005), enhancing a pre-existing awareness of the possible international repercussions of any new intervention. Moreover, starting from 2007, the military became the target of a series of coup plot investigations and many highranking officers were either imprisoned or pacified, the result being the further consolidation of the AKP's political rule.

In sum, the major pillar of the AKP's strategy of reproduction was based first and foremost on political survival. Naturally, this longer-term strategy of gradually establishing the party as the sole source of institutional power in Turkey had to contend with strong challenges. It slowly pushed the military into its barracks, incentivizing secularist capitalist forces' compliance as well as disciplining labour while presenting itself as a democratizing force in the Middle East and its neighbourhood to the West. This alignment with the West, in a word, was more a pragmatic strategy directed primarily towards domestic aims, that is, the consolidation of the AKP's power, juridically, socially, electorally and materially. Except for an early brief period of disjuncture between the American and Turkish foreign policies following the 2003 invasion of Iraq, Turkish external strategy generally complemented that of the US as a result.

Throughout the whole period the AKP has been in power, favourable global circumstances of capital accumulation have helped to sustain an average five per cent growth rate. Recovery from the 2001 major Turkish banking crisis had already started under the auspices of the former World Bank official Kemal Derviş, according to an IMF plan maintained by the AKP during its first term. The subsequent major restructuring of Turkish finance and regulatory oversight had a cleansing effect. It increased growth to 6.8 per cent on average between 2002 and 2007 (OECD 2012) before a 4.7 per cent contraction in 2009 due to the global recession. High growth rates, high interest rates and low inflation attracted speculative foreign capital and foreign direct investment (FDI), though this mostly took the 
form of mergers and acquisitions (Öniş 2009, 426) rather than green field developments. Speculative short-term finance capital inflows created a credit boom and an overvalued Turkish lira, which in turn increased demand for imports. This sustained the vulnerability to speculative FDI, which, together with expanding energy needs, led to a growing current account deficit. Despite this and high unemployment rates, the main indicators of macroeconomic performance seemed positive and broadly in line with the IMF targets. Successful expansion combined with favourable global economic circumstances, and growth peaked at 9.0 per cent in 2010 (TurkStat 2011), outpacing Chinese growth rates.

These macroeconomic conditions were essential for the AKP's strategy of reproduction in two ways. First, the general public endorsed unprecedented levels of socio-economic stability, in which hyperinflation, austerity and decades of crises were finally overcome. This was attractive to all parts of the population. Second, the benefits of growth were shared amongst established Republican capital, rising Anatolian capital and the labouring poor and small shopkeepers, all of whom were now better off as a result of credit abundance.

Building on Özal's export-oriented accumulation strategy, the AKP also sought to diversify Turkish export markets, breaking with the traditional isolationist regional foreign policy. Turkey now eyed the untapped former Ottoman geography, seizing on (perceived or real) cultural affinities. Turkish foreign policy activism during the AKP era, expressed in the formulae 'strategic depth' and 'zero problems' with its neighbours, developed by the former foreign and current prime minister Ahmet Davutoğlu ${ }^{22}$ is now addressed to the entire post-Ottoman world, including the Caucasus, the Balkans, Africa and the Middle East. Maintaining a realist and at times indeed imperial (Özkan 2014) understanding of Turkey's geopolitical position, situated 'between Asia and Europe', Davutoğlu's approach claims to overcome conventional security restrictions of the 'contender state' (Pijl 2007, 219) by understanding Turkey's central position as an opportunity for liberal trade expansion and soft-power projection.

In the context of successful regional expansion, especially in the construction sector, the outbreak of the so-called Arab Spring movements in the region posed both challenges and opportunities (Öniş 2012). Along with the West, Ankara was caught by surprise and failed to formulate effective and consistent policy responses. As the spread of the revolutionary wave throughout the region seemed irreversible, Turkey selectively supported uprisings and opposed dictators. In Egypt, where the Muslim Brotherhood was a strong contender for power in the post-revolutionary period, Turkey, remembering its own not-so-recent past of ruling generals, was quick to declare its opposition to the army's rule under the Mubarak regime. In Libya, by contrast, where it had billions of dollars of investment and thousands of workers, Turkey vocally opposed a possible intervention by NATO, an institution it is formally part of. Eventually Turkey, too, called for Qaddafi's resignation and contributed to the NATO operation. Closer to home, it was the Syrian case that proved by far the most difficult for Turkey, having various domestic implications. Encouraged by the temporary rise of the Muslim Brotherhood to

${ }^{22}$ Ahmet Davutoğlu set out his thesis of stratejik derinlik or 'strategic depth' for the first time in 2001 (Davutoğlu 2001). For the continuities between Kemalists and post-Kemalist Islamists see Birch (2008). 
power in Cairo under President Morsi, Turkey sought to emulate these results in Syria and across the region. Spearheading efforts to bring the Assad regime down, the AKP hoped to build friendly Sunni Islamist regimes in Egypt, Syria, Palestine and elsewhere, consolidating its power from the Horn of Africa to Sarajevo. Indeed, by May 2013 things seemed to be unfolding the way the AKP government wanted. Davutoğlu's long-standing prediction regarding the rise of Islamic movements to power seemed to be coming true in the Middle East (Özkan 2014). Egypt was ruled by the Muslim Brotherhood, the Syrian opposition was gaining ground against regime forces, and relations with the KRG in Iraq were extremely friendly, though it irritated both the PKK and, of course, the central government in Baghdad with close ties to Teheran. Though US policymakers were not happy with Turkish-Israeli tensions as well as Turkey's independent foreign policy initiatives, Washington refrained from any open challenge, hoping that Turkey would do America's bidding in Syria. This general constellation led to the two NATO allies concluding an agreement over the use of Incirlik airbase for the anti-IS coalition's war efforts in July 2015.

Simultaneously, the Anglo-Saxon financial press and investors raced to praise the Turkish market. The government and the Central Bank of the Republic of Turkey (TCMB) responded to the remaining concerns about the soaring current account deficit, rising energy needs, cheap imports and credit abundance with an unorthodox policy mix of increasing the reserve requirements of banks while keeping interest rates low. Again the construction sector played a central role in addressing the current account deficit by exporting material and services to oiland gas-producing trade partners such as Russia, Iran, Iraq and Libya. In March 2013 the Financial Times declared Turkey the 'true Iraq War victor' — a war Turkey did not take part in-due to its successes in winning most of the contracts in Iraq as well as its soaring exports to this country (Dombey and Güler 2013). These policies proved fruitful at least in terms of macroeconomic indicators and the Turkish economy saw a soft landing by the end of 2012 with growth rates decreasing to 2.2 per cent and the deficit falling from US\$77.2 billion in 2011 to US\$48.9 billion in 2012, representing, respectively, 10.0 and 6.0 per cent of gross domestic product (GDP), so that by May 2013 a second credit rating agency increased Turkey's rating to investment grade, and government yields saw historic lows in return. ${ }^{23}$

In part a reaction to the construction-fuelled growth regime, the outbreak of the Gezi protests in May 2013 and a graft scandal implicating many members of the cabinet in December of the same year struck a heavy blow to the government domestically. The protests marked the limits of the AKP's domestic developmentalism as well as calling into question its democratic credentials. The scope of its so-called 'conservative democratic' rhetoric became obvious as the security forces killed several and injured thousands of largely peaceful protestors. The graft scandal, in turn, both uncovered the widespread network of corrupt and illegal relations between the government, pro-government corporations, pro-government businessmen and pro-government media and drove a wedge between the government and its allies among the ranks of the followers of US-based Islam-

23 'Moody's upgrades Turkey', Wall Street Journal, 20 June 2012, <http:/ /online.wsj.com/news / articles/SB10001424052702304898704577478030788960276>, accessed 12 May 2014. 
ic preacher Fethullah Gülen. The government and particularly Prime Minister Erdoğan claimed that both the Gezi protests and the graft investigation were part of the same international conspiracy involving the 'interest rate lobby', 'Jewish lobby' and 'others who could not digest Turkey's rise'.

The response to these domestic challenges consisted of increasing authoritarianism and attempts to consolidate the AKP's power base using more unorthodox means. After providing a workable resolution to Turkey's long-standing 'social question' in the form of so-called 'conservative democracy' modelled on the European Christian democrats, the AKP abandoned this enterprise and alienated half of the population as it consolidated the other half as its core constituency. At the same time, the ousting of Morsi in Egypt by the hated military and the failure of the international community to decisively support the opposition in Syria disappointed Turkey's assertive strategies based on strengthening the Muslim Brotherhood as the main social force likely to guarantee Turkish influence as well as electoral success abroad. The fallout with the West in general and the US in particular over a variety of regional issues ranging from the Turkish missile defence system tender, to deteriorating relations with Israel, Turkey's turning a blind eye to IS militants' activities, the matter of marketing KRG oil without Baghdad's consent and the related larger problem of Iraq's territorial integrity lent support to arguments about Turkey's 'axis shift'. So much so that the Turkish government described its status in international relations as 'worthy solitude' or 'precious isolation', ${ }^{24}$ which had come to replace the 'zero problems' doctrine.

Debates on the 'axis shift', however, referred mostly to the period preceding this latest episode of increasing authoritarianism at home and isolation abroad, when the TFP was considered relatively proactive, creative and assertive. ${ }^{25}$ Resolving the 'social question' had enabled the AKP government to project power abroad, significantly from 2008 onwards building on the newfound strength of Turkey's economy. Further growth led to the further penetration of old and new, tapped and untapped markets alike. These included the Middle East, North, East and West Africa as well as other neighbouring states to the north. Even though the traditional destination of Turkish exports, the EU, suffered from crisis related low demand, this market, too, remained a strong target. Growing export markets remains essential as Turkey's growing economy and energy demand create vulnerabilities to short-term financial inflows and its chronically deepening current account deficit.

With Turkey's socio-economic, domestic and geopolitical fortunes undergoing a deepening crisis, the AKP's strategy of social reproduction entered into a critical phase in 2015. Increasing inflation, shrinking exports, a widening current account deficit and the Turkish lira coming under pressure in international monetary markets are but a few signs of its main electoral strategy being compromised. This

24 “"Zero problems" policy supplanted by "precious loneliness" approach', Today's Zaman, 25 August 2013, <http://www.todayszaman.com/news-324415-zero-problems-policy-supplanted-byprecious-loneliness-pproach.htm>, accessed 15 May 2014.

${ }^{25}$ Kennedy and Dickenson (2013) specifically cite two developments, that is, the deterioriating relations with Israel starting with the Mavi Marmara incident and Turkey's cooperation with Brazil in offering a draft agreement for the resolution of Iran's nuclear ambitions. 
coincided with the successful strategy of the Peoples' Democratic Party (Halklarin Demokrasi Partisi, HDP), entering parliament with 13 per cent of the votes, thus effectively destroying the parliamentary majority the AKP had held since 2002 and the project of introducing a Russian-style presidential system, empowering its former party leader turned elected president Recep Tayyip Erdoğan. In the aftermath of this electoral defeat, the coalition forming process with the main opposition Republican People's Party (Cumhuriyet Halk Partisi, CHP) was compromised by an anti-terror campaign targeting left-wing and Kurdish opposition forces politically, militarily and legally. This bid to regain a parliamentary majority by mobilising ultra nationalist votes proved to be successful in the November 12015 snap elections, restoring the AKP's single party government. ${ }^{26}$ At the same time, reacting to territorial gains of Kurdish forces in northern Syria bordering Turkey, the $\mathrm{AKP}^{\prime}$ 's caretaker government re-engaged the US as a means to regain lost international legitimacy, emphasizing Turkey's geostrategic value as a partner in the anti-IS struggle while preventing further Kurdish territorial gains (Matin 2015).

Insofar as the AKP's strategies of reproduction complemented the wider American-led Western strategies of reproduction in the Middle East, Turkey's relatively independent foreign policy still seemed liberal and 'pro-Western'. As soon as the same independent foreign policy changed its responses to changing circumstances, it did not seem 'pro-Western' anymore. Finally, Turkey's position is reported to have 'changed' yet again, taking an active combatant role against IS in line with American expectations. However, change was never from a 'proWestern' to an 'Islamic' or 'Eastern' direction. It reflects the changing strategies of social reproduction of the governing AKP. Within an increasingly polarized Turkish society and increasing international dislocations, the AKP lost its ability to project power successfully, electorally and geopolitically alike. While the AKP consolidated itself as the sole source of political-institutional rule in Turkey, the perception of the government that every major domestic (for example, Gezi protests, 7 June elections) and international development (for example, Kurdish territorial gains in Syria) is a threat to its political survival prevents it from responding effectively to the regional and international challenges Turkey faces. The current foreign policy impasse may well show signs of inconsistency and 'failure'. It is nevertheless intelligible in the light of the ruling party's strategy of reproduction in its current state.

\section{Conclusion}

At the time of writing this conclusion the Turkish Armed Forces (TSK) are conducting their first large-scale participation in a war on foreign soil since the 1974 invasion of Cyprus. On the night of 24 July 2015, the Turkish Air Force started bombing IS targets in Syria as well as PKK positions in northern Iraq. Operations against the PKK have since intensified, while the IS has not since been targeted by Turkish military forces. In the light of increased domestic and international tensions, deploying the concept of Pax Turca may seem wholly misguided. However, beyond an unprecedented willingness to engage in foreign affairs militarily by a government formally voted out of office, this latest episode demonstrates two

\footnotetext{
${ }^{26}$ At the time of writing, the results of this process were still unknown.
} 
things. First, Turkish foreign-policy-making is indeed a complex process from the 'Pan-Turanism' (Aras 2000) of the 1990s, to 'Eurasianism' (Akçali and Perinçek 2009), to the AKP's alleged 'Islamist hegemony' (Tuğal 2007). All of these have provoked contradictory analyses that don't lend themselves easily to existing explanations or simplified 'models' or 'identities'. Rather than reflecting an 'identity shift' towards 'Islamism', TFP is now dominated by concerns about security similar to those of the Republican governments of the 1990s, the officers of the 'deep state' whom the AKP had sought to discredit and imprison until 2011 now becoming its closest domestic allies. Rather than turning its back to the West, the AKP government has struck a substantial deal with the US, which keeps emphasizing the government's 'right to self-defence against PKK attacks' ${ }^{27}$ Lastly, rather than the use of violent force being dictated by purely materialist interests, orchestrated by a Turkish or transnational bourgeoisie, we see a deliberate escalation of violence defying all previously sacred growth and expansion imperatives. In short, the current conjuncture in TFP does not lend itself easily to a preconceivedmodelofaxisshift. Rather,currenteventssuggest thedeepconnection of Turkish foreign-policy-making to its Ottoman-Turkish roots, not least in its intricate Kurdish dimensions.

This article constitutes an attempt to understand the contemporary, seemingly contradictory foreign policy dynamics by tracing the historical roots of changing strategies of social reproduction. The thus explained contemporary Turkish strategy, or Pax Turca, then, is a part of the AKP's larger strategy of reproduction that initially manifested as an attempt to consolidate the party as the sole source of political rule in Turkey-traditionally an exclusive domain for Turkey's military-bureaucratic establishment-through securing high levels of electoral support at any cost, including foreign intervention, and then as a larger geographical projection of the AKP's geopolitical vision. This, in turn was dependent on continuing economic growth, leading to the expansion of export markets, including those in former Ottoman territories with lower levels of competition. Turkey's new self-understanding does not stop at the former Ottoman borders, though. Demonstrating aspirations for the country to be a global power, Turkish foreign-policy-makers rhetorically commit to such concepts as global justice, development, humanitarianism and human rights, public demanding reforms of the United Nations (UN) security architecture and the world's power structures at large. Economic growth, moreover, has also allowed fiscal recovery generating a solid budget surplus, funding the provision of public services and 'development' more generally (or the idea thereof) in Turkey's peripheries, but also continued military investments, including a burgeoning national defence industry. Hence, the combination of regional and global power projection and strong growth figures help us to understand the AKP's electoral strategies with all their domestic and international implications. In turn, this also means, that the ruling party has become dependent on growth as the key to its triumph at the ballot box. Besides a middle-income trap (Yeldan et al 2013), this strategy bears considerable other risks. The dramatic events following the June 2015 elections speak volumes in this

${ }^{27}$ Despite the recent deal to base US fighter jets at the Incirlik base, the exact details of which are not clear at the time of writing, considerable differences in opinion over the future of Syria remain between the two long-standing allies (Bertrand 2015). 
regard. While the strong focus on trade used to be complemented by a strategy of expanding industrial manufacture, this has now been overtaken by a focus on the construction and real estate sectors. Though similarly part of Turkey's export strategy, this sector not only shows all signs of a property bubble akin to that in some Western economies prior to the financial crisis of 2008, but the inflating energy demand stemming from this hydrocarbon-based growth agenda is also contributing significantly to a growing current account deficit, leading to a higher dependency on global financial markets and associated monetary woes (Raiser 2015). The attempt to generate new alliances within Turkey and abroad to help the AKP stay in power has now led to considerable blowbacks and a dramatic challenge to the AKP's power. Despite these underlying contradictions and risks, the three-pronged, electoral, political-economic and foreign policy strategy of social reproduction certainly represents social change. Most notably in the way in which large parts of the society relate to the state. It does not, however, indicate an axis shift from a pro-Western to an Islamic or Eastern orientation-something Turkey could ill afford-as Turkey's foreign policies were never pro-Western in the first place. Change, we argue, is a reflection of the changing strategies of reproduction of the Turkish government in response to perceived challenges both within and outside Turkey.

Finally, theoretically, this emphasis on the historical constitution of strategies of social reproduction offers distinctive advantages over traditional FPA approaches for three key reasons. First, it allows for a plurality of agents and their spatio-temporally variable rationales to be accounted. In the present case it decodes 'Turkey' as a 'rational actor' and relates foreign-policy-making to the larger strategy of social reproduction by one specific agent, the AKP, not without, however, relating this process to other agents' strategies. Second, the concrete historicization of the geopolitical conjunctures their interactions generate and through which their actions are mediated provides an improved understanding of the specific socio-political environment(s) within which all concerned agents continue to socially reproduce. Third, the social-relational historical approach advocated here helps to overcome disciplinary constraints imposed by economics, sociology, history, geopolitics and FPA relating agents to socio-historically specific and malleable structures instead of developing mutually exclusive voluntarist inside-out explanations or deploying hermetically sealed systemic accounts leaving little to no space for agency.

\section{Notes on contributors}

Clemens Hoffmann is an assistant professor at Bilkent University, Ankara. He received his $\mathrm{PhD}$ from the University of Sussex in 2010. He works on the relationship between political authority and ecology from a historical materialist perspective. His regional interests include the entire post-Ottoman world and Turkey's foreign policy towards the non-Western world in particular. He has published in Cooperation and Conflict, Global Environmental Change and Environment and Planning $C$.

Can Cemgil lectures on the MA programme in IR at Istanbul Bilgi University. He received his PhD from the University of Sussex in 2015. He has co-authored an article in Globalizations on the role of dialectics in IR and FPA. His research inter- 
ests include international historical sociology, FPA, international relations of the Middle East and international political economy.

\section{References}

Al-Ahmeh, A (1993) Islams and modernities (London: Verso)

Akçalı, E and M Perinçek (2009) 'Kemalist Eurasianism: an emerging geopolitical discourse in Turkey', Geopolitics, 14:3, 550-569

Anderson, P (2008) 'Kemalism', London Review of Books, 30:17, 3-12

Aras, B (2000) 'Turkey's policy in the former Soviet south: Assets and options', Turkish Studies, 1:1, 36-58

Atabaki, T and EJ Zurcher (eds) (2004) Men of order: authoritarian modernization under Atatürk and Reza Shah (London: IB Tauris)

Atasoy, S (2011) 'The Turkish example: a model for change in the Middle East?', Middle East Policy, 18:3, 86-100

Ayata, B (2015) 'Turkish foreign policy in a changing Arab world: rise and fall of a regional actor?', Journal of European Integration, 37:1, 95-112

Bertrand, N (2015) ‘US military official: "We were outraged" when Turkey pulled a fast one right after the anti-ISIS deal', Business Insider UK, 11 August, $<<$ http: / / uk.businessinsider. com/us-and-turkey-tension-in-isis-fight-2015-8?r=US\&IR=T\#ixzz3iWgG0obM>>, accessed 11 August 2015

Bilgic, A (2015) "“We are not barbarians": gender politics and Turkey's quest for the West', International Relations, 14 January 2015, doi: 10.1177/0047117814565524

Bilgin, P (2007) "“Only strong states can survive in Turkey's geography": the uses of "geopolitical truths" in Turkey', Political Geography, 26:7, 740-756

Birch, N (2008) 'We are all Kemalists', Prospect, 146, <<http://www.prospectmagazine. co.uk/magazine/weareallkemalists $>>$, accessed 19 August 2014

Bloxham, D (2005) The great game of genocide: imperialism, nationalism and the destruction of the Ottoman Armenians (Oxford: Oxford University Press)

Bookchin, M (1982) The ecology of freedom (Palo Alto (CA: Cheshire Books))

Braude, B and B Lewis (1980) Christians and Jews in the Ottoman Empire: the functioning of a plural society (New York, NY: Holmes \& Meier)

Brenner, R (1985a) 'Agrarian class structure and economic development in pre-industrial Europe' in TH Ashton and CHE Philpin (eds) The Brenner debate: agrarian class structure and economic development in pre-industrial Europe (Cambridge, United Kingdom: Cambridge University Press), 10-63

Brenner, R (1985b) 'The agrarian roots of European capitalism' in TH Ashton and CHE Philpin (eds) The Brenner debate: agrarian class structure and economic development in preindustrial Europe (Cambridge, UK: Cambridge University Press), 213-327

Brenner, R (1986) 'The social basis of economic development' in John Roemer (ed) Analytical Marxism (Cambridge, United Kingdom: Cambridge University Press), 23-53

Buğra, A (1998) 'Class, culture, and state: an analysis of interest representation by two Turkish business associations', International Journal of Middle East Studies, 30:4, 521-539

Çağaptay, S (2006) Islam, secularism and nationalism in modern Turkey: who is a Turk? (London: Routledge)

Çağaptay, S (2011) 'Turkish foreign policy under the AKP: the rift with Washington', The Washington Institute for Near East Policy, Policy Notes, 3: 1-15

Cam, S (2002) 'Neo-liberalism and labour within the context of an "emerging market" economy-Turkey', Capital \& Class, 26:2, 89-114

Cheterian, V (2014) "Turkey and the "Islamic State"', Open Democracy, 23 September, $<<$ https://www.opendemocracy.net/vicken-cheterian/turkey-and-islamicstate $\% \mathrm{E} 2 \% 80 \% 9 \mathrm{D}>>$, accessed 21 January 2015

Cornell, SE (2012) 'What drives Turkish foreign policy?', Middle East Quarterly, Winter, 2012: 13-24

Coş, K and P Bilgin (2010) 'Stalin's demands: constructions of the "Soviet other" In Turkey's foreign policy, 1919-1945', Foreign Policy Analysis, 6:1, 43-60 
Davutoğlu, A (2001) Stratejik Derinlik, Turkiye'nin Uluslararasi Konumu [Strategic depth, Turkey's international position] (Istanbul: Kure Yayinlari)

Davutoğlu, A (2008) 'Turkey's foreign policy vision', Insight Turkey, 10:1, 77-96

Davutoğlu, A (2012) 'Principles of Turkish Foreign policy and regional political structuring', TEPAV Turkey Policy Brief Series, <<http://www.tepav.org.tr/upload/ files/1336135395-4.Principles_of_Turkish_Foreign_Policy_and_Regional_Political_ Structuring_by_Ahmet_Davutoglu.pdf $\gg>$, accessed 24 January 2015

Demir, F (2005) 'Militarization of the market and rent-seeking coalitions in Turkey', Development and Change, 36:4, 667-690

Demir, Ö, A Mustafa and M Toprak (2004) 'Anatolian Tigers or Islamic capital: prospects and challenges', Middle Eastern Studies, 40:6, 166-188

Demirtaş-Bagdonas, Ö (2012) 'A shift of axis in Turkish foreign policy or a marketing strategy? Turkey's uses of its "uniqueness" vis-à-vis the West/Europe', Turkish Journal of Politics, 3:2, 111-132

Demirtaş-Bagdonas, Ö (2014) 'Reading Turkey's foreign policy on Syria: the AKP's construction of a great power identity and the politics of grandeur', Turkish Studies, $15: 1,139-155$

Deringil, S (1989) Turkish foreign policy during the Second World War: an 'active' neutrality (Cambridge, UK: Cambridge University Press)

Dombey, D and F Güler (2013) 'Turkey emerges as true Iraq War victor', Financial Times, 12 March, <<http:/ /www.ft.com/intl/cms/s/0/c038427a-8a40-11e2-bf79-00144feabdc0. html $>>$, accessed 10 October 2014

Edelman, ES et al (2013) 'The roots of Turkish conduct: understanding the evolution of Turkish policy in the Middle East', Bipartisan Policy Center National Security Program, Foreign Policy Project, $<<$ http:/ / bipartisanpolicy.org/wp-content/uploads / sites/default/files/The\%20Roots\%20of\%20Turkish\%20Conduct.pdf $>>$, accessed 20 February 2015

Güneş, C (2012) The Kurdish national movement in Turkey: from protest to resistance (London: Routledge)

Hale, W (2000) Turkish foreign policy, 1774-2000 (London: Frank Cass)

Halliday, F (2002) 'For an international sociology' in S Hobden and J Hobson (eds) Historical sociology of international relations (Cambridge, UK: Cambridge University Press), 244-264

Heydarian, RJ (2011) 'Arab Spring, Turkish harvest', Foreign Policy in Focus, 22 September, $<<$ http:/ / fpif.org/arab_spring_turkish_harvest $>>$, accessed 23 January 2015

Hoffmann, C (2008) 'The balkanization of Ottoman rule: premodern origins of the modern international system in Southeastern Europe', Cooperation and Conflict, 43:4, 373-396

Hoşgör, E (2011) 'Islamic capital/ Anatolian Tigers: past and present', Middle Eastern Studies, $47: 2,343-360$

Islamoglu, H (2004) The Ottoman Empire and the World Economy (Cambridge, UK: Cambridge University Press)

Islamoglu, H and C Keyder (1977) 'Agenda for Ottoman history', Review, 1:1, 31-55

Karpat, KH (2000) 'Historical continuity and identity change or how to be modern Muslim, Ottoman and Turk' in KH Karpat (ed) Ottoman past and today's Turkey (Leiden: Brill), $1-28$

Kavakç1, M (2009) 'Turkey's test with its deep state', Mediterranean Quarterly, 20:4, 83-97

Kennedy, R and M Dickenson (2013) 'Turkish foreign policy and public opinion in the AKP era', Foreign Policy Analysis, 9:2, 171-188

Keyder, C (1987) State and class in Turkey: a study in capitalist development (London: Verso)

Lapointe, T and FG Dufour (2012) 'Assessing the historical turn in IR: an anatomy of second wave historical sociology', Cambridge Review of International Affairs, 25:1, 97-121

Leffler, MP (1985) 'Strategy, diplomacy, and the Cold War: the United States, Turkey, and NATO, 1945-1952', Journal of American History, 71:4, 807-825

Lippe, JMV (2000) 'Forgotten brigade of the forgotten war: Turkey's participation in the Korean War', Middle Eastern Studies, 36:1, 92-102

Mardin, S (1969) 'Power, civil society and culture in the Ottoman Empire', Comparative Studies in Society and History, 11:3, 258-281

Marois, T (2012) States, banks and crisis: emerging finance capitalism in Mexico and Turkey (Cheltenham (Edward Elgar): United Kingdom) 
Matin, K (2015) 'Why is Turkey bombing the Kurds?', Open Democracy, 4 August, <<https: / www.opendemocracy.net/arab-awakening/kamran-matin/why-is-turkey-bombingkurds $>>$, accessed 5 August 2015

McDowall, D (2004) A modern history of the Kurds (London: IB Tauris)

Michaud-Emin, L (2007) 'The restructuring of the military high command in the seventh harmonization package and its ramifications for civil-military relations in Turkey', Turkish Studies, 8:1, 25-42

OECD (2012) Country Statistical Profile: Turkey 2010

Öniş, Z (1997) 'The political economy of Islamic resurgence in Turkey', Third World Quarterly, 18:4, 743-766

Öniş, Z (2004) 'Turgut Özal and his economic legacy: Turkish neo-liberalism in critical perspective', Middle Eastern Studies, 40:4, 113-134

Öniş, Z (2006) 'Globalization and party transformation: Turkey's Justice and Development Party in perspective' in P. Burnell and A. W. M. Gerrits (eds) Globalizing democracy: party politics in emerging democracies (London: Routledge), 1-27

Öniş, Z (2009) 'Beyond the 2001 financial crisis: the political economy of the new phase of neo-liberal restructuring in Turkey', Review of International Political Economy, 16:3, $409-432$

Öniş, Z (2012) 'Turkey and the Arab Spring: between ethics and self-interest', Insight Turkey, $14: 3,45-63$

Öniş, Z (2014) 'Turkey and the Arab revolutions: boundaries of regional power influence in a turbulent Middle East', Mediterranean Politics, 19:2, 203-219

Özkan, B (2014) 'Turkey, Davutoglu and the idea of pan-Islamism', Survival, 56:4, 119-140

Özpek, BB and Y Demirağ (2014) 'Turkish foreign policy after the "Arab Spring": from agenda-setter state to agenda-entrepreneur state', Israel Affairs, 20:3, 328-346

Pamuk, S (2000) 'Intervention during the Great Depression-another look at the Turkish experience' in S Pamuk and G Jeffrey (eds) The Mediterranean response to globalization before 1950 (London: Routledge), 321-339

Parla, T (1985) The social and political thought of Ziya Gokalp, 1876-1924 (Leiden: Brill)

Pijl, K Van Der (2007) 'Capital and the state system: a class act', Cambridge Review of International Affairs, 20:4, 619-637

Raiser, M (2015) 'From know-who to know-how: Turkey and the "middle income trap"', Brookings Institution Blog, 19 February, <<http://www.brookings.edu/blogs/futuredevelopment/posts/2015/02/19-turkey-middle-income-trap-raiser $>>$, accessed 24 February 2015

Robins, P (2003) Suits and uniforms: Turkish foreign policy since the Cold War (Seattle, WA: University of Washington Press)

Rodinson, M (1966) Islam et capitalisme (Paris: Seuil)

Şenyüz, S and F Balıkçı (2015) 'PM Davutoğlu wants a new Middle East for Turks, Kurds, Arabs', Hurriyet Daily News, 25 January, <<http://www.hurriyetdailynews. com / pm-davutoglu-wants-a-new-middle-east-for-turks-kurds-arabs. aspx?PageID=238\&NID=77427\&NewsCatID=338>>, accessed 19 January 2015

Söyler, M (2013) 'Informal institutions, forms of state and democracy: the Turkish deep state', Democratization, 20:2, 310-334

Tasspınar, Ö (2014) 'The end of the Turkish model', Survival, 56:2, 49-64

Teschke, B (2003) The myth of 1648: class, geopolitics, and the making of modern international relations (London: Verso)

Teschke, B and H Lacher (2007) 'The changing logics of capitalist competition', Cambridge Review of International Affairs, 20:4, 565-580

Teschke, B and C Cemgil (2014) 'The dialectic of the concrete: reconsidering dialectic for IR and foreign policy analysis', Globalizations, 11:5, 605-625

Tuğal, C (2007) 'NATO's Islamists', New Left Review, 1:44, 5-34

Tuğal, C (2009) Passive revolution: absorbing the Islamic challenge to capitalism (Stanford, CA: Stanford University Press)

TurkStat (2011) 'The gross domestic product, 2nd quarter', Press Release no. 186, Turkish Statistical Institute, Ankara

Weber, M (1920) 'Die protestantische Ethik und der Geist des Kapitalismus' in Gesammelte Aufsätze zur Religionssoziologie, vol 1 (Tübingen: Mohr Siebeck), 17-206; transl Talcott 
Parsons (1958) The Protestant ethic and the spirit of capitalism (New York: Charles Scribner's Sons)

Wood, EM (1981) 'The separation of the economic and the political', New Left Review, 1:127, 66-95

Yalman, GL (2009) Transition to neoliberalism—the case of Turkey in the 1980s (Istanbul: Bilgi University Press)

Yalvaç, F (2014) 'Approaches to Turkish foreign policy: a critical realist analysis', Turkish Studies, 15:1, 117-138

Yarkin, G (2015) 'The ideological transformation of the PKK regarding the political economy of the Kurdish region in Turkey', Kurdish Studies, 3:1, 26-46

Yavuz, MH (1998) 'Turkish identity and foreign policy in flux: the rise of neo-Ottomanism', Middle East Critique, 7:12, 19-41

Yavuz, MH (2003) Islamic political identity in Turkey (Oxford: Oxford University Press)

Yeginsu, C and H Cooper (2015) 'U.S. jets to use Turkish bases in war on ISIS', New York Times, 23 July, <<http://www.nytimes.com/2015/07/24/world/europe/turkey-isisus-airstrikes-syria.html $>>$, accessed 10 August 2015

Yeldan, AE (1995) 'Surplus creation and extraction under structural adjustment: Turkey, 1980-1992', Review of Radical Political Economics, 27:2, 38-72

Yeldan, AE, Taşçı, K., Voyvoda, E., and Özsan, E. (2013) Orta Gelir Tuzağı'ndan Çıkış: Hangi Türkiye, vol 2. Bölgesel Kalkınma ve Ikili Tuzaktan Çıkış Stratejileri [Breaking the middleincome trap: which turkey, vol 2. Regional development and strategies for breaking the double trap] (Istanbul: TURKONFED)

Zürcher, EJ (2004) Turkey: a modern history (London: IB Tauris) 